\title{
NONMARKET VALUATION OF CULTURAL AND ENVIRONMENTAL IMPACTS OF SUSTAINABLE CITY TOURISM IN VIENNA, AUSTRIA
}

\author{
PETRA AMRUSCH \& FRANZ WIRL \\ University of Vienna, Austria
}

\begin{abstract}
The main purpose of this paper is to monetarily assess the effect of cultural and natural goods and services on tourism in Vienna, Austria. By means of hedonic modelling, we investigate how the value of tourist places, cultural and natural monuments is capitalized in commercial housing prices. First, in the context of variable selection, main tourist attractions are identified. In the second section, by controlling for accessibility effects of transportation, the investigation area is defined. Using hedonic regression analyses, the tourists' willingness to pay for the adjacency to monuments is quantified. Finally, results obtained are used to illustrate the influence of sustainable city tourism on the preservation of cultural and natural monuments. There are particular important trade-offs between preservation and new construction.

Keywords: hedonic model, nonmarket valuation of cultural goods and services, accessibility to monuments in sustainable tourism.
\end{abstract}

\section{INTRODUCTION}

Studies show not only a positive relationship between historic preservation and housing prices, but also a positive impact of protection on environmental sustainability. For instance, Gilderbloom et al. [1, p. 97] found out that people living within historic districts display more environmentally friendly lifestyles than "those residing in higher-density, new-build apartment complexes and condos". Natural and cultural goods and services can be defined as non-market use and non-use values or preservation values [2]. Although "use does not require the physical proximity of the user and the resource", according to Freeman et al. [2], use can be defined "to include the purchase of a complementary market good that embodies some visual or literary representation of the resource" [2, pp. 113-114]. Empirical literature on hedonics shows that also cultural and natural intangible goods not traded on the market are capitalized in complementary market goods, such as housing. According to booking.com reviews "guests loved walking around the neighbourhood" of a hotel close to cultural heritage in Vienna [3].

Irrespective of tourists' intentions to protect the environment [4], sustainability of innercity tourism is enhanced if tourists prefer to walk rather than using transport services (causing environmental costs, e.g., emissions to the air [5]). Landon et al. [6, p. 2] suggest that "tourists have the ability to act as force for good based on how they spend their money and the specific behaviors they adopt to minimize the harm that they impose on other people and the environment" [5]-[6]. López-Guzmán et al. [7, p. 4] define motivation as "one of the most important explanatory factors of the aspects related to tourist activity".

Accordingly, the question could be posed whether inner-city tourists in Vienna are motivated to pay additional sums to be able to reach attractions within walking distance (regardless of visiting or walking around the attractions). One aim of the paper is to assess whether tourists are implicitly willing to pay for walkable proximity to cultural heritage attractions. Are inner-city tourists disposed to pay additional sums for staying in hotels or apartments located close to a monument (as a subcategory of tangible cultural heritage [8])? 
Is there an observable relationship between the demand for accommodation and the proximity to different immovable monuments? Besides, what is the value in monetary terms tourists attach to monumental proximity? We address these questions applying hedonic models in order to quantify the monetary value of vicinity from cultural heritage is assessed.

\section{METHODOLOGY AND DATA}

\subsection{Variable construction and selection}

In the valuation of the effect of proximity to central monuments we apply the hedonic model [9]-[11] referred to as a revealed preference approach of nonmarket valuation. Contrarily, the stated preference surveys draw the "data from people's responses to hypothetical questions rather than from observations of real-world choices" [2, p. 25]. Typically, in tourism research [12]-[13], the advertised accommodation prices are regressed on a set of attributes.

Coefficients on attributes, such as monumental proximity, can be determined by regressing the actual accommodation price against the accommodation attributes. Following hedonic pricing literature [2, p. 314] it is assumed that in equilibrium the derived marginal implicit prices of accommodation characteristics "must be equal to the corresponding marginal willingness to pay for those characteristics".

According to Freeman "it must be acknowledged that there are many respects in which the actual data diverge from the theoretical ideal and in which the assumptions about the nature of the housing market and preferences are oversimplifications. But the question is not whether the model is perfect, but rather does it provide a usable vehicle for increasing our knowledge" [14, p. 171]. "Because of the information provided by such data, it is typically necessary for analysts to make assumptions about preferences so that models can be estimated with the data" [2, p. 24]. As deduced by the ranking of tourist activities in Vienna from TripAdvisor [15], the most popular things tourists do in Vienna include visiting the city core and inner-city monuments: the visitation of the Former Imperial Palace and St. Stephen's Cathedral is among the top five out of 717 tourist activities (such as city and private tours, the visitation of architectural buildings, museums, parks, gardens, symphonies, cemeteries, zoos, theatres). There may be also other motives for the willingness to pay for monumental adjacency (such as prestige or just walking around the monuments); supporting the hypothesis that monumental adjacency enters utility functions of inner-city tourists.

The hedonic model is estimated for the segment of small groups (of two people) with no children per room taking into account that the representative city tourist is relatively young, travels preferably with the partner and stays shorter than the average tourist [16]. In January 2018, the average length of stay was about two days in hotels and pensions in Vienna [17].

Geographical and temporal variations in tourism activity may reflect differences in the motivations of tourists.

Possible preference heterogeneity [11] is preferably a priori taken into account in data collection. It could be argued that going sightseeing in the historical city is seasonally independent. Data on 794 actual price observations per two people (as dependent variable denoted by PRICE) were gained using booking.com [18] in the low season at a point of time (on the 15th of January 2018) of less special city highlights (e.g., the Open-Air Danube Island Festival (Donauinselfest), the New Year's Eve Trail in the Old City). A few properties have been excluded from the sample, e.g., an outlier located 19,000 metres from the downtown, accommodations with a minimum length of stay of more than one night and fully booked properties revealing difficulties in the appraisal of the accommodation price per night. 
In explaining the variation in actual accommodation prices, independent variables were collected, i.e., accommodation-specific attributes, location-specific characteristics and other accommodation features such as review score (denoted by REVIEWSCORE) and location score regarded if relatively high (LOCATION) via booking.com [18].

In hedonic models, the use of perceived values rather than measured ones is preferred [2]. In analysing properties with high location scores, the location score is highlighted in addition to the general rating score of reviews (partially including LOCATION) [18]. Thus, even though REVIEWSCORE includes location, a further variable has been constructed, REVIEWSCORE+LOCATION, by summing up the values of REVIEWSCORE and LOCATION (for high location scores).

$0 / 1$ dummy variables indicate whether an accommodation offers an additional service (such as breakfast or the use of a pool) or not, i.e., an accommodation with a pool included was coded one, otherwise zero (denoted by DPOOL). Moreover, a $0-5$ category dummy variable has been created for the star ranking of a hotel, DSTAR. Ranking dummy variables have been built with the value one for the 10 most central accommodations and the values two, three and four, grouping the top 11-20, top 21-30, top 31-40 accommodations in term of distance from the centre, respectively, and zero otherwise. Additionally, data on the distance from the centre in metres were collected. Using booking.com [18], a further 0/1 public transport accessibility dummy variable (DMETRO) was created, equalling one if the accommodation is close to the metropolitan line, and zero, otherwise. Moreover, information on the apartment size in terms of square metres (SQM) and number of persons sleeping (CAPACITY) has been gathered for each apartment, using the same source [18].

\subsection{Accommodation prices in Vienna}

Table 1 displays the mean price per two people per night for all types of accommodation providers (hotels, pensions, hostels and apartments and apartment houses) in Vienna in the middle of January 2018 [18].

The geographical variations in accommodation prices suggest regional heterogeneity and the existence of submarkets to be controlled for. In the sample, the most central accommodation can be found on a central square (Stephansplatz) and the most distant observations are located about 11,000 metres from the downtown in green areas.

Mean prices are highest in the centre (I district) that is characterised by high monumental density. The XIII district (with, e.g., the Schönbrunn Palace as attraction) is the second most expensive district. The average prices in the outlying districts are somewhat higher compared to semi-central districts. For instance, the XXII district is positioned close to the Danube River with, e.g., the Danube Tower (Donauturm) as tourist attraction [19]. This stresses the importance of monuments as it can dominate distance. The three top visited tourist attractions (the St. Stephen's Cathedral (I district), the Schönbrunn Palace (XIII district) and the Schönbrunn Zoo (XIII district)) are located in the two most expensive districts, considering a summary ranking list of most visited attractions in 2013 [19]. The accommodations are located in zones differing with respect to various aspects that have to be considered in a

Table 1: Mean accommodation prices in 23 districts (I-XXIII) [18].

\begin{tabular}{|c|c|c|c|c|c|c|c|c|c|c|}
\hline & I & $\begin{array}{c}\text { II- } \\
\text { IX }\end{array}$ & $\begin{array}{c}\text { X- } \\
\text { XII }\end{array}$ & XIII & $\begin{array}{c}\text { XIV- } \\
\text { XV }\end{array}$ & $\begin{array}{c}\text { XVI- } \\
\text { XVII }\end{array}$ & $\begin{array}{c}\text { XVIII- } \\
\text { XIX }\end{array}$ & XX & $\begin{array}{c}\text { XXI- } \\
\text { XXII }\end{array}$ & XXIII \\
\hline$€$ & 148 & 99 & 90 & 128 & 87 & 106 & 92 & 117 & 107 & 100 \\
\hline
\end{tabular}


hedonic model (walkability in terms of pedestrian areas and sidewalks, densities of cultural and natural heritage, distance from the downtown, traffic densities, open space, distance from public transport services, accommodation types and characteristics, etc.). For instance, hostels are geographically concentrated in the central and semi-central districts close to the downtown. Typically, in the outlying districts, apartments can also be found in bungalows or low-rise buildings in the open space. The identification of spatial patterns suggests that district-specific inhomogeneity (particularly in terms of monumental densities and adjacency to public transport) should be controlled for in the hedonic model, i.e., via market segmentation [21].

\section{DEFINITION OF THE STUDY AREA AND TOURIST ATTRACTIONS}

Tourist attractions are spread all over the city of Vienna, from the city centre to the rural urban fringe including, i.e., the Viennese hills and the Danube Island. The vicinity to one monument might be correlated with the proximity to another one. In order to avoid spatial intercorrelations between monuments, the investigation area is to be delineated by selecting, i.e., only inner-city accommodations and monuments agglomerated within a walkable distance. Concerning environmental sustainability, it is to be noted, that central attractions are typically close to pedestrian areas or at least adjacent to "continuous and well-maintained sidewalks" [20, p. 163]. By including in the sample inner-city tourist accommodations, we can cope with heterogeneity of cultural tourists' preferences and the district-specific variations. By delineating the historical core within which homogeneity is assumed, i.e., in terms of walkability, historical centre-specific characteristics, location-specific characteristics such as distance from the city core and the metropolitan line, we defined a submarket of inner-city properties within a walkable distance. The submarket consists of the most central 306 observations on hotels (130), pensions (18), hostels (5) and apartments (152) from the total of 794 accommodations spread all over the 23 districts. The observations were ranked by the distance in terms of metres from the core of the city using booking.com [18]. The selected central observations are mainly located in the first district.

By estimating the hedonic model for the city core the sample homogeneity is increased since no inner-city observation is close to a main railway station (Westbahnhof (XV), Hauptbahnhof (X)), for the accessibility effect of which a distinctive model has to be set up.

Spatial accessibility effects of the public transport system are controlled for, considering that all selected observations (apartments, hotels, hostels and pensions) are located close to the metropolitan line (connected with the railway stations) and usually to an airport shuttle [18]. In contrast, bearing in mind the whole sample across districts, possible public transport externalities could be capitalized in prices due to variations in DMETRO in the outlying areas which benefit less from the proximity to transport services as well as due to other transportrelated specifics, such as the density of hop-on-hop-off tourist bus routes and fiacre carriage and taxi stops. Information on the properties' distances from five landmarks was obtained using booking.com [18] and collected in terms of units of metres (rounded off to nearest 100). These five tourist attractions are also advertised by different providers of tourist services [22]-[27]. For theoretical reasons in testing several (logarithmic) functional forms, a monumental distance of zero (rounded off) was converted into the distance of 20 metres for one observation [3], [18]. Mean distances from the attractions are given in Table 2, differentiated between hotels and apartments. Correspondingly, mean prices are displayed in Table 3. Considering inner-city accommodations as a starting point, inner-city tourists walk about 1,100 (1,104) metres and 1,000 (990) metres to visit the Former Imperial Palace (Hofburg) (distance variable denoted by IMPERIALPALACE) and the St. Stephen's Cathedral (denoted by STSTEPHENSCATHEDRAL), respectively. The mean distance to 
Table 2: Accommodation distance from five landmarks [18].

\begin{tabular}{|l|c|c|c|c|c|c|c|c|}
\hline \multirow{2}{*}{$\begin{array}{l}\text { Attraction } \\
\text { (monument) }\end{array}$} & \multicolumn{6}{|c|}{ Distance (in terms of metres) from the attraction } \\
\cline { 2 - 10 } & Mean & Median & Max. & Min. & Mean & Median & Min. & Max. \\
\cline { 2 - 9 } \\
$\begin{array}{l}\text { Hofburg (Former } \\
\text { Imperial Palace) }\end{array}$ & $\mathbf{1 , 1 0 4}$ & $\mathbf{1 , 0 0 0}$ & $\mathbf{2 , 3 0 0}$ & $\mathbf{3 0 0}$ & $\mathbf{1 , 1 5 0}$ & $\mathbf{1 , 0 0 0}$ & $\mathbf{4 0 0}$ & $\mathbf{2 , 4 0 0}$ \\
\hline $\begin{array}{l}\text { Riesenrad (Giant } \\
\text { Ferris Wheel) }\end{array}$ & 2,135 & 2,150 & 3,600 & 300 & 1,895 & 1,800 & 500 & 3,600 \\
\hline Prater (Vienna Prater) & 2,212 & 2,200 & 3,700 & 400 & 1,973 & 1,900 & 600 & 3,700 \\
\hline $\begin{array}{l}\text { Schloss Schönbrunn } \\
\text { (Schönbrunn Palace) }\end{array}$ & 5,008 & 5,000 & 6,700 & 3,300 & 5,235 & 5,200 & 3,400 & 6,800 \\
\hline $\begin{array}{l}\text { Stephansdom (St. } \\
\text { Stephen's Cathedral) }\end{array}$ & $\mathbf{9 9 0}$ & $\mathbf{1 , 0 0 0}$ & $\mathbf{1 , 8 0 0}$ & $\mathbf{2 0}$ & $\mathbf{8 5 2}$ & $\mathbf{8 0 0}$ & $\mathbf{1 0 0}$ & $\mathbf{1 , 8 0 0}$ \\
\hline
\end{tabular}

Table 3: Mean accommodation price in the centre per two people per night [18].

\begin{tabular}{|l|c|c|}
\hline Accommodation type & $\begin{array}{c}\text { Mean price in } € \text { for } \\
\text { two people per night }\end{array}$ & $\begin{array}{c}\text { Median price in } € \text { for } \\
\text { two people per night }\end{array}$ \\
\hline Hotel (per 2 people = double room) & $\mathbf{1 2 3}$ & $\mathbf{1 0 1}$ \\
\hline Apartments (per 2 people) & $\mathbf{1 4 4}$ & $\mathbf{1 1 9}$ \\
\hline
\end{tabular}

the Giant Ferris Wheel (GIANTFERRISWHEEL), the Vienna Prater (PRATER) and the Schönbrunn Palace (SCHÖNBRUNNPALACE) ranges from about 2,000 to 5,000 metres. Comparable distances to tourist attractions are displayed in the column of apartments.

It is to be noted that the St. Stephen's Cathedral and the Former Imperial Palace (both close to pedestrian areas and continuous sidewalks) could be considered comparable in terms of walkability [20] and with respect to the distance in terms of metres, while the distance is larger from the Giant Ferris Wheel, the Prater and the Schönbrunn Palace to inner-city properties.

\section{THE HEDONIC MODEL AND RESULTS}

After running OLS regressions (using Eviews 10) for the full sample of inner-city properties $(\mathrm{N}=306)$, it was found preferable using subsets of apartments and hotels rather than the whole data set of hotels, apartments, pensions and hostels [21]. As pointed out by Kummerow and Galfalvy [21], using uniform samples could give a better prediction, but it inclines to reduce the predictor variables (as well as the $\mathrm{R}^{2}$ ).

\subsection{Hedonic regressions for two subsamples}

By using disaggregated sets of 57 hotels and 109 apartments, semi-log-specifications were found to fit best the data, explaining about $58 \%$ and $41 \%$ of the variance of $\ln (\boldsymbol{P R I C E})$, respectively. The explanatory power is satisfactory, considering that the use of homogenous sample sets decreases the range of independent variables [21], [28]. The computation of Huber-White-Hinkley ( $\mathrm{HC1}$ ) heteroskedasticity consistent estimates in the regressions resulted in highly significant coefficients (Table 4 and Table 5) with signs as expected. 
Table 4: Hedonic model for hotels.

\begin{tabular}{|l|c|}
\hline \multirow{2}{*}{ Constant and variables } & OLS-Regression results \\
\cline { 2 - 2 } & $\begin{array}{c}\text { Coefficients (with } \\
\text { absolute t-statistics in } \\
\text { parentheses) }\end{array}$ \\
\hline Constant & $\mathbf{- 1 3 . 7 9 ( 3 . 9 )}$ \\
\hline LN(STSTEPHENSCATHEDRAL+IMPERIALPALACE) & $\mathbf{- 0 . 2 7 ( 3 . 2 )}$ \\
\hline DPOOL & $\mathbf{0 . 6 7}(3.6)$ \\
\hline LN(REVIEWSCORE+LOCATION) & $\mathbf{6 . 9 8}(4.8)$ \\
\hline DSTAR & $\mathbf{0 . 0 7}(3.2)$ \\
\hline $\begin{array}{l}\text { N }=57, R^{2}=0.58, \\
\text { DURBIN-WATSON STAT.: } 1.7, \text { JARQUE-BERA STAT.: } 2.53 \\
\text { DEP. VARIABLE = LN(PRICE) }\end{array}$ \\
\hline
\end{tabular}

Table 5: Hedonic model for apartments.

\begin{tabular}{|l|c|}
\hline \multirow{2}{*}{ Constant and variables } & OLS-Regression results \\
\cline { 2 - 2 } & $\begin{array}{c}\text { Coefficients (with } \\
\text { absolute t-statistics in } \\
\text { parentheses) }\end{array}$ \\
\hline Constant & $\mathbf{3 . 0 8}(3.4)$ \\
\hline LN $($ RE VIEWSCORE $)$ & $\mathbf{1 . 1 7}(2.9)$ \\
\hline LN(STSTEPHENSCATHEDRAL+IMPERIALPALACE$)$ & $\mathbf{- 0 . 1 8}(2.5)$ \\
\hline CAPACITY & $\mathbf{- 0 . 1 0}(3.0)$ \\
\hline SQM & $\mathbf{0 . 0 0 4 5}(3.2)$ \\
\hline $\begin{array}{l}\text { N=109, R }{ }^{2}=0.41, \\
\text { DURBIN-WATSON STAT.: 2.2, JARQUE-BERA STAT.: } 2.48 \\
\text { DEP. VARIABLE = LN(PRICE) }\end{array}$ \\
\hline
\end{tabular}

\subsection{Hedonic regression results}

Prior to including predictors into the regressions, several variables were tested separately and jointly for significance and for multicollinearity. The distance from the furthermost attractions, the Giant Ferris Wheel, the Wiener Prater and the Schönbrunn Palace, was not found to be statistically significant (at a 0.1 level) in both hedonic regressions. The estimation results are plausible since these landmarks are not located within a walkable distance from inner-city properties (due to the large distance and the reduced walkability on continuous sidewalks/pedestrian areas consistent with definitions of walkability [20]. In order to visit the Schönbrunn Palace, inner-city tourists would have to walk on average additional four kilometres. The average distance to the Giant Ferris Wheel and the Wiener Prater is double compared to the proximity to both centrally located attractions (St. Stephen's Cathedral and the Former Imperial Palace). In this context, the trade-off between length of stay and accommodation costs of inner-city tourists should be discussed, considering the accessibility of these remoter attractions by public and private transport. Consequently, a separate analysis of these submarkets (Schönbrunn Palace and Wiener Prater including the Giant Ferris Wheel) would be useful. The distances to the St. Stephen's Cathedral and to the Former Imperial 
Palace were found to be per se statistically significant in both regressions at conventional significance levels. The sum of both distance variables was selected for inclusion into the regressions standing for the monumental distance: the variable $\ln$ (STSTEPHENSCATHEDRAL+IMPERIALPALACE) is significantly related to prices (Table 4 and Table 5). As expected, the adjacency of hotels and apartments to the St. Stephen's Cathedral plus the Imperial Palace is negatively correlated with accommodation prices, holding other coefficients constant. If the monumental distance is about $10 \%$ smaller, people are willing to pay around 3\% more for a double hotel room. In other words, if a hotel is about 200 metres (around $10 \%$ of the sum of the average monumental distances $(1,104+$ 990 metres (in Table 2)) closer to the Former Imperial Palace and the St. Stephen's Cathedral, tourists are disposed to pay on average additional $€ 3(2.7 \%$ of the average hotel price of $€ 123$ $=€ 3.30$ ) per day per double hotel room (see Table 3). A 10\% reduction (on average 200 metres) in distance from the Former Imperial Palace plus the St. Stephen's Cathedral implies a daily apartment price mark-up of about $1.8 \%$ or around $€ 3$ (i.e., about $1.8 \%$ of the average apartment price of $€ 144=€ 2.60)$ per two people. The marginal willingness to pay per two people per night weighted according to the type of accommodation establishments (apartments and hotels) comes to around $€ 2.80$ (and around $€ 1.4$ per one person per night (approximately $50 \%$ of $€ 2.80$ )) The willingness to pay for monumental adjacency is substantial, in view of, e.g., the number of bed nights in the city centre in one year. By multiplying, i.e., the total number of bed nights registered in the first district (I) in all accommodation establishments in 2016, 2,566,709 [29], by $€ 1.4$ (the marginal willingness to pay for monumental adjacency of one person per night weighted according to the type of accommodation establishments (apartments and hotel)), the total willingness to pay for monumental adjacency of 200 metres would average out at a sum between $€ 3,000,000$ and $€ 4,000,000$, assuming comparable marginal willingness to pays for monumental adjacency of tourists staying overnight in other types of accommodation establishments (apart from hotels and apartments).

Interestingly, although regressions differ with respect predictors, inner-city hotel and apartment-tourists are willing to pay similar amounts in monetary terms for the monumental proximity. Soler and Gemar [30], using TripAdvisor ratings in a recent hedonic study for Malaga, mentioned as a specific condition of hotels' location, i.e., pedestrian zones. Tourists might appreciate walking-friendly environments. In Vienna, clusters of inner-city cultural and natural heritage as well as pedestrian areas are spatially correlated. In view of that, it is to be added that the Former Imperial Palace and the St. Stephen's Cathedral are "connected" via pedestrian areas (Kärnterstraße, Graben, Kohlmarkt). Besides, nearby the Former Imperial Palace, a cluster of other attractions surrounded by large spaces of pedestrian areas and squares can be visited without crossing major roads, such as the Spanish Riding School, the National Library and the Museums (Imperial Butterfly House, etc.), Churches (Minoriten Church, etc.), Parks (People's Garden, etc.), and so forth [22]-[27]. (Further attractions, such as museums (Art History, etc.), the Burgtheater, the Parliament, and the Opera are located in the proximity as well.) Hotel-tourists premium extra high location scores in combination with review scores, giving attention to the sum of REVIEWSCORE and LOCATION, whereas the apartment price is merely correlated with REVIEWSCORE. $\ln ($ LOCATION) as well as $\ln (\boldsymbol{R E V I E W S C O R E}+\mathbf{L O C A T I O N})$ are not statistically significant (and not included) in the regression of Table 5 for apartments. Only review ratings, largely including location as

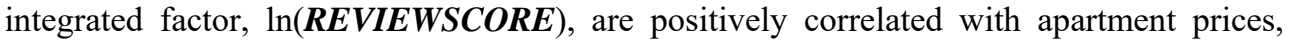
implying that inner-city apartment-tourists might perceive location differently. In the subsample of hotels, the coefficient on $\ln (\boldsymbol{R E V I E W S C O R E + L O C A T I O N})$ displays a significant and large price impact. It could be added that $\ln (\boldsymbol{R E V I E W S C O R E})$ is 
significantly correlated with hotel prices. However, the inclusion of $\ln (\boldsymbol{R E V I E W S C O R E}+\mathbf{L O C A T I O N})$ was found to contribute to an improved regression performance in Table 4 for hotels. As anticipated, the DSTAR and DPOOL are positively correlated with the hotel price. Inner-city apartment-tourists attach importance to the apartment size, as expected, holding other factors constant, the surface, $\mathbf{S Q M}$, is positively correlated with price. Reasonably, CAPACITY is negatively correlated with the dependent variable, implying that for every additional person the apartment price declines.

\section{SUMMARY RESULTS AND CONCLUDING REMARKS}

This study quantified the positive impact of cultural heritage on the hospitality business in monetary terms by taking into account attractions within a walkable distance.

Inner-city tourists are willing to pay additional sums for the proximity to cultural heritage (on average, $€ 3$ per night per two people). Thereby, positive valuations of monumental adjacency are also coherent with preferences for sustainable behaviour of inner-city cultural tourists in terms of walkability. This is very topical in Vienna, because a projected high-rise building threatens Vienna's status as cultural heritage by UNESCO. The quantitative results obtained on monumental proximity are consistent with qualitative review statements [3]. Irrespective of visiting the monuments (once or more times) or just walking in the neighbourhood [3] or staying near the monuments for other reasons, inner-city hotel and apartment-tourists are willing to pay additional sums for staying in accommodations in walkable distance from the St. Stephen's Cathedral and the Former Imperial Palace whose on-site visit is a leading tourist activity in Vienna [15]. Soler and Gemar [30, p. 1] also proposed hoteliers how to allocate resources and pointed out that hedonic price models are an "interesting tool for management and research". Further conclusions can be also drawn for the inner-city hospitality sector in Vienna, considering the price elasticities of review ratings of hotels and apartments. Apartment-tourists give attention to the apartment size, whereas hotel-tourists attach more importance to other accommodation attributes (such as star ranking, the availability of a pool). An increase in apartment size of around ten square metres is related to an about $5 \%$ rise in price. On average, hotel-tourists are willing to pay almost twice the price (additional 95\% of the price) for a pool included. One additional star is associated with about a 7\% price increase. Location is differently valued by hotel- and apartment-tourists. While the adjacency to monuments is similarly important for hotel- and apartment-tourists in monetary terms, inner-city hotel-tourists "add" an extra highlighted location score to the review scores in their valuations, while apartment-tourists focus on the overall review score. Irrespective of the accessibility by public transport due sample homogeneity, inner-city hotel-tourists are willing to pay additional sums for high review scores combined with extra high location scores. The intrinsic conservation of cultural heritage within pedestrian areas is valuable also for investment decisions in the hospitality business and sustainable behaviour in tourism. In line with international literature findings, historic districts and preservation indeed induces investment decisions as well as environmental behaviour not only of inhabitants, but also of tourists [1]. Also for Vienna investments close to well-maintained cultural heritage might be profitable for individuals and the environment. Studies confirm [1, p. 98] that "historic property owner feels that their investment is more secure in historic districts because their neighbourhoods are not only preserved, but also are well maintained". Thus, intrinsic conservation of cultural heritage capitalized in the hospitality sector affects environmental sustainability and investment decisions. Studies show that authenticity is a common factor of cultural heritage tourism places, regardless of commercialisation [31]. As concluded by Hughes and Carlsen, "conservation of cultural heritage authenticity and integrity is obviously important in terms 
of maintaining social and cultural value for the greater public good" [31, pp. 30-31]. Therefore, trade-offs of preservation and new construction could be estimated by the additional inference of effects of cultural heritage capitalized in market goods and services of other sectors, irrespectively of physical proximity, e.g., cultural heritage can be valued also by persons not in the physical proximity of the good or service [2]. Among others, future investigation possibilities could be the deference of the tourists' willingness to pays for nonmarket goods and services in other districts of Vienna (e.g., nearby the Schönbrunn Palace) or the exploration of changes in implicit prices over time. It would be interesting to compare results with future and existing hedonic studies on cultural heritage and to conduct similar empirical studies in other tourist designations of the world. Freeman emphasizes the importance of empirical evidence in hedonic modelling: when "such associations are found in repeated statistical experiments with different data sets and different cities, they tend to support the hypothesis" [14, p. 159].

\section{REFERENCES}

[1] Gilderbloom, J.I., Hanka, M.J. \& Ambrosius, J.D., Historic preservation's impact on job creation, property values, and environmental sustainability. Journal of Urbanism, 2(2), pp. 83-101, 2009.

[2] Freeman, A.M., III, Herriges, J.A. \& Kling, C.L. (eds), The Measurement of Environmental and Resource Values: Theory and Method, RFF Press: Washington, DC, 2014.

[3] Booking.com B.V., Hotel Am Stephansplatz, www.booking.com/hotel/at/ stephansplatz.en-gb.html. Accessed on: 19 Feb. 2018.

[4] Juvan, E. \& Dolincar, S., Measuring environmentally sustainable tourist behavior. Annals of Tourism Research, 59, pp. 30-44, 2016.

[5] Boley, B.B., To travel or not to travel? Both have implications for sustainable tourism. Tourism Planning \& Development, 12(2), pp. 208-224, 2015.

[6] Landon, A.C., Woosnam, K.M. \& Boley, B.B., Modeling the psychological antecedents to tourists' pro-sustainable behaviors: An application of the value-belief norm model. Journal of Sustainable Tourism, 2018. https://doi.org/10.1080/ 09669582.2017.1423320.

[7] López-Guzmán, T., Torres Naranjo, M., Pérez Gálvez, J.C. \& Carvache Franco, W., Segmentation and motivation of foreign tourists in world heritage sites. A case study, Quito (Ecuador). Current Issues in Tourism, 2017. https://doi.org/10.1080/13683500.2017.1344625.

[8] UNESCO, What is meant by "cultural heritage"? www.unesco.org/new/en/culture/ themes/illicit-trafficking-of-cultural-property/unesco-database-of-national-culturalheritage-laws/frequently-asked-questions/definition-of-the-cultural-heritage/. Accessed on: 4 Feb. 2018.

[9] Rosen, S., Hedonic prices and implicit markets: Product differentiation in pure competition. Journal of Political Economy, 82, pp. 34-55, 1974.

[10] Freeman, A.M., III, On estimating air pollution control benefits from land value studies. Journal of Environmental Economics and Management, 1(1), pp. 74-83, 1974.

[11] Turner, R.K. (ed), Sustainable Environmental Economics and Management: Principles and Practice, Belhaven Press: London, pp. 120-226, 1993.

[12] White, P.J. \& Mulligan, G.F., Hedonic estimates of lodging rates in the Four Corners Region. The Professional Geographer, 54(4), pp. 533-543, 2002.

[13] Hamilton, J.M., Coastal landscape and the hedonic price of accommodation. Ecological Economics, 62(3-4), pp. 594-602, 2007. 
[14] Freeman, A.M., III, Hedonic prices, property values and measuring environmental benefits: A survey of the issues. The Scandinavian Journal of Economics, 81(2), pp. 154-173, 1979.

[15] TripAdvisor, www.tripadvisor.at/Attractions-g190454-Activities-Vienna.html. Accessed on: 21 Feb. 2018.

[16] Österreich Werbung, www.austriatourism.com/themen/stadt/. Accessed on: 6 Jan. 2018.

[17] MA 23, www.wien.gv.at/statistik/wirtschaft/tabellen/uebernlaender.html; Wiener Tourismusverband, https://b2b.wien.info/de/statistik/daten/statistik-aktuell. Accessed on: 21 Mar. 2018.

[18] Booking.com B.V., www.booking.com/. Accessed on: 6 Jan. 2018.

[19] Wikipedia, Meistbesuchte Sehenswürdigkeiten Wiens, https://de.wikipedia.org/wiki/ Meistbesuchte Sehenswürdigkeiten Wiens. Accessed on: 3 Feb. 2018.

[20] Hutabarat Lo, R., Walkability: What is it? Journal of Urbanism, 2(2), pp. 145-166, 2009.

[21] Kummerow, M. \& Galfalvy, H., Error trade-offs in regression appraisal methods. Real Estate Valuation Theory. Research Issues in Real Estate, eds K. Wang \& M.L. Wolverton, Springer: Boston, MA, 2002.

[22] Travel Guides by the Experts, www.planetware.com/tourist-attractions-/vienna-a-wvie.htm. Accessed on: 4 Feb. 2018.

[23] AboutVienna.org, www.aboutvienna.org/sights/sights.php. Accessed on: 4 Feb. 2018.

[24] Vienna Tourist Boardwww.wien.info/en/sightseeing/sights. Accessed on: 4 Feb. 2018.

[25] Vienna Sightseeing Tours, www.viennasightseeing.at/de_DE/hop-on-hop-off/ stadtspaziergang. Accessed on: 4 Feb. 2018.

[26] TripAdvisor, www.tripadvisor.in/Attractions-g190454-Activities-Vienna.html. Accessed on: 4 Feb. 2018.

[27] Michelin Travel, https://travelguide.michelin.com/europe/austria/vienna/vienna/tovisit. Accessed on: 4 Feb. 2018.

[28] Morton, T.G., Narrow versus wide stratification of data in the development of regression appraisal models. Real Estate Economics, American Real Estate and Urban Economics Association, 4(2), pp. 7-18, 1976.

[29] MA 23, www.wien.gv.at/statistik/wirtschaft/tabellen/uebern-bezirk-zr.html. Accessed on: 4 Feb. 2018.

[30] Soler, I.P. \& Gemar, G., Hedonic price models with geographically weighted regression: An application to hospitality. Journal of Destination Marketing \& Management, 2018. https://doi.org/10.1016/j.jdmm.2017.12.001.

[31] Hughes, M. \& Carlsen, J., The business of cultural heritage tourism: critical success factors. Journal of Heritage Tourism, 5(1), pp. 17-32, 2010. 